\title{
Effects of two fermentable carbohydrates (inulin and resistant starch) and their combination on calcium and magnesium balance in rats
}

\author{
Hassan Younes, Charles Coudray*, Jacques Bellanger, Christian Demigné, Yves Rayssiguier and \\ Christian Rémésy \\ Centre de Recherche en Nutrition Humaine d'Auvergne, Unité Maladies Métaboliques et Micronutriments, Centre de \\ Recherche INRA Clermont-Ferrand/Theix, 63122 Saint-Genès-Champanelle, France
}

(Received 7 December 2000 - Revised 20 April 2001 - Accepted 7 June 2001)

\begin{abstract}
Resistant starch and inulin are complex carbohydrates that are fermented by the microflora and known to increase colonic absorption of minerals in animals. The fermentation of these substrates in the large bowel to short-chain fatty acids is the main reason for this increase in mineral absorption. The purpose of the present study was to examine the potential synergistic effect of a combination of these two fermentable carbohydrates. For this purpose, thirty-two adult male Wistar rats weighing $200 \mathrm{~g}$ were used in the present study. The rats were distributed into four groups, and fed for $21 \mathrm{~d}$ a fibre-free basal purified diet or diet containing $100 \mathrm{~g}$ inulin, or $150 \mathrm{~g}$ resistant starch (raw potato starch)/kg diet or a blend of $50 \mathrm{~g}$ inulin and $75 \mathrm{~g}$ resistant starch $/ \mathrm{kg}$ diet. After an adaptation period of $14 \mathrm{~d}$, the rats were then transferred to metabolic cages and dietary intake, faeces and urine were monitored for $5 \mathrm{~d}$. The animals were then anaesthetized and caecal $\mathrm{Ca}$ and $\mathrm{Mg}$ absorption were measured. Finally, the rats were killed and blood, caecum and tissues were sampled. $\mathrm{Ca}$ and $\mathrm{Mg}$ levels were assessed in diets, faeces, urine, caecum and plasma by atomic absorption spectrometry. Our results confirmed that inulin and resistant starch ingestion led to considerable caecal fermentation in the three experimental groups compared with the control group diet. Moreover, both carbohydrates significantly increased the intestinal absorption and balance of $\mathrm{Ca}$ and $\mathrm{Mg}$, without altering the plasma level of these two minerals. Interestingly, the combination of the studied carbohydrates increased significantly $(P<0.05)$ the caecal soluble $\mathrm{Ca}$ and $\mathrm{Mg}$ concentrations, the apparent intestinal absorption and balance of $\mathrm{Ca}$, and non-significantly the plasma $\mathrm{Mg}$ level. In conclusion, a combination of different carbohydrates showed synergistic effects on intestinal $\mathrm{Ca}$ absorption and balance in rats. Further studies with other types of carbohydrate combinations should be carried out to extend these findings.
\end{abstract}

Fermentable carbohydrates: Inulin: Resistant starch: Short-chain fatty acids: Calcium and magnesium: Intestinal absorption: Rat

\begin{abstract}
Many reports have indicated that $\mathrm{Ca}$ can be significantly absorbed and $\mathrm{Mg}$ is mainly absorbed from the large intestine, namely the caecum and the colon (Ebel \& Gunther, 1980; Allen, 1982; Hardwick et al. 1990; Brink \& Beynen, 1992; Kayne \& Lee, 1993). Fermentable carbohydrates reach the large intestine to be used by the local microflora. They may stimulate bifidobacteria and lactobacilli growth in the intestine, which has been proposed to be connected with health-promoting functions (Gibson et al. 1995; Kruse et al. 1999). Many other beneficial health effects for fermentable carbohydrates have been already reported, concerning diabetes and lipid
\end{abstract}

metabolism and cancer prevention (de Deckere et al. 1993; Younes et al. 1995; Jackson et al. 1999). Several investigations have demonstrated that rats fed fermentable carbohydrates absorbed more $\mathrm{Ca}$ and $\mathrm{Mg}$ than control rats, despite an increase in total faecal mass (Ohta et al. 1994, 1995, 1996; Delzenne et al. 1995).

Carbohydrate fermentation can influence the intestinal absorption of $\mathrm{Ca}$ and $\mathrm{Mg}$ in many ways. The short-chain fatty acid (SCFA), fermentation products, are responsible for decreasing caecal content $\mathrm{pH}$, which in its turn increases mineral solubility to improve mineral absorption. The SCFA can also directly influence mineral absorption by

\footnotetext{
Abbreviations: RS, resistant starch; SCFA, short-chain fatty acids.

* Corresponding author: Dr Charles Coudray, fax +33 4736246 38, email coudray @clermont.inra.fr
} 
complexing with the minerals leading to an increase in their absorption. The caecal enlargement can also increase the surface area exchange to improve mineral absorption (Demigné et al. 1989; Rémésy et al. 1993; Younes et al. 1993). These different aspects are closely linked to the nature of studied fermentable carbohydrates and to mineral concentrations (Ohta et al. 1994, 1995, 1996; Younes et al. 1996). The enhancing effect of inulin on $\mathrm{Ca}$ and $\mathrm{Mg}$ absorption has been investigated several times in animals (Levrat et al. 1991a; Delzenne et al. 1995) and human subjects (Coudray et al. 1997a; Coudray \& FairweatherTait, 1998; Van den Heuvel et al. 1998). Resistant starches (RS) have been examined in animals and also showed enhancing effects on $\mathrm{Ca}$ and $\mathrm{Mg}$ absorption (Rayssiguier \& Rémésy, 1977; Morais et al. 1996; Younes et al. 1996; Lopez et al. 1998). Foods are a complex mixture containing different relative molecular masses and concentrations of fermentable carbohydrates. The complexity and the variety of these later components may allow maintenance of high fermentation activity throughout the large intestine, which can increase their beneficial effects on mineral absorption. Only a few studies have tried to determine the combined effects of different fermentable carbohydrates on SCFA production and hence mineral absorption (Topping et al. 1985; Campbell et al. 1997).

The aim of the present study was to investigate the potential synergistic effect of a blend of two different fermentable carbohydrates on fermentation variables and on the caecal as well as the apparent intestinal absorption of $\mathrm{Ca}$ and $\mathrm{Mg}$ and on their plasma level in rats.

\section{Materials and methods}

\section{Animals and diets}

Thirty-two male Wistar rats (derived from the colony of laboratory animals of the National Institute of Agronomic Research, Clermont-Ferrand/Theix, France) were fed a commercial pellet diet (U.A.R., Villemoisson s/Orge, France) until body weights reached about $200 \mathrm{~g}$ (8 weeks). Groups of eight rats were fed for $21 \mathrm{~d}$ a basal (fibre-free) purified diet, or diets containing $100 \mathrm{~g}$ inulin $/ \mathrm{kg}, 150 \mathrm{~g}$ $\mathrm{RS} / \mathrm{kg}$ or a blend of $50 \mathrm{~g}$ inulin and $75 \mathrm{~g} \mathrm{RS} / \mathrm{kg}$ (Table 1). RS was a crude potato starch supplied by Louis François, StMaur, France. It is worth noting that up to $750 \mathrm{~g} / \mathrm{kg}$ starch was RS (Andrieux et al. 1989). Inulin (or chicory inulin) was supplied by ORAFTI, Tienen, Belgium. The degree of polymerization of this inulin ranges from 3 to 50, with an average of 9. Inulin contains $1000 \mathrm{~g}$ indigestible carbohydrate/kg while crude potato starch contains only $750 \mathrm{~g}$ fermentable carbohydrates $/ \mathrm{kg}$. That is why we have chosen an inulin:crude potato starch ratio of $1: 1.5$ to obtain similar levels of fermentations, and to compare then, the effect of their combination. Diet $\mathrm{Ca}$ and $\mathrm{Mg}$ levels were about 7500 and $900 \mathrm{mg} / \mathrm{kg}$ respectively. The rats were provided with fresh food and distilled water daily; these were available $\mathrm{ad}$ libitum. During the period of adaptation (14d), the rats were housed two per cage (wire-bottomed to limit coprophagy) and maintained in a temperature-controlled room $\left(22^{\circ} \mathrm{C}\right)$ with the dark period from 20.00 hours to 08.00 hours. Following the adaptation phase, rats were individually housed for additional $7 \mathrm{~d}$ in metabolic cages fitted with urine-faeces separators to collect faeces and urine (experimental phase). Food consumption and body weight were recorded twice per week during the adaptation phase, then daily during the $7 \mathrm{~d}$ experimental phase. Urine (acidified by $\mathrm{HCl}$, final $5 \mathrm{mmol} / \mathrm{l}$ ) and faeces were collected during the last $5 \mathrm{~d}$ of the experiment for determination of mineral balance. The animals were maintained and handled according to the recommendations of the Institutional Ethic Committee of the University of Clermont-Ferrand, France.

\section{Sampling procedures}

The rats were killed just after the dark period (between 08.00 and 10.00 hours), because caecal fermentation was still very active. After anaesthesia (40 mg sodium pentobarbital $/ \mathrm{kg}$ ), the rats were maintained on a warming plate at $37^{\circ} \mathrm{C}$. The procedure of blood sampling for the measurement of arteriovenous difference across the caecum has been described previously (Demigné \& Rémésy, 1985). For blood flow measurement, bromosulfophthalein in saline

Table 1. Composition of experimental diets $(\mathrm{g} / \mathrm{kg})$

\begin{tabular}{lrrcc}
\hline Diets... & Fibre-free & Inulin & Resistant starch & Inulin+resistant starch \\
\hline Ingredients: & 160 & 160 & 160 & 160 \\
Casein & 720 & 620 & 570 & 595 \\
Wheat starch & 0 & 100 & 0 & 50 \\
Inulin & 0 & 0 & 150 & 75 \\
Crude potato starch & 50 & 50 & 50 & 50 \\
Corn oil & 60 & 60 & 60 & 60 \\
AIN salt mix $§$ & 10 & 10 & 10 & 10 \\
AIN vitamin mix $¥ \S$ & 10 & & & \\
\hline
\end{tabular}

* Wheat starch was extensively purified and contains $0 \mathrm{~g}$ of resistant starch or NSP/kg.

† AIN salt mixture $(\mathrm{g} / \mathrm{kg})$ : calcium phosphate dibasic 500 , sodium chloride 74 , potassium citrate monohydrate 220 , potassium sulfate 52 , magnesium oxide 24 , manganese carbonate $(430-480 \mathrm{~g} \mathrm{Mn} / \mathrm{kg}) 3.5$, ferric sulfate $(160-170 \mathrm{~g} \mathrm{Fe} / \mathrm{kg}) 6$, zinc carbonate $(700 \mathrm{~g} \mathrm{Zn} / \mathrm{kg}) 1.6$, copper carbonate $(530-550 \mathrm{~g} \mathrm{Cu} / \mathrm{kg}) 0.3$, potassium iodate 0.01 , sodium selenite 0.01 , chromium potassium sulfate 0.55 , sucrose, finely powdered 118 .

¥AIN vitamin mixture $(\mathrm{mg} / \mathrm{kg})$ : thiamine hydrochloride 600 , riboflavin 600 , pyridoxine hydrochloride 700 , nicotinic acid 3000 , D-calcium pantothenate 1600 , folic acid 200, D-biotin 20, cyanocobalamin (vitamin $B_{12}$ ) 1 , retinyl palmitate (vitamin A) pre-mix 1600, DL- $\alpha$-tocopherol acetate 20000 , cholecalciferol (vitamin $D_{3}$ ) 250, menaquinone (vitamin $\mathrm{K}_{2}$ ) 50 , sucrose, finely powdered $972.9 \mathrm{~g}$.

$\S$ Mineral and vitamin mix were purchased from UAR (Villemoisson, Epinay-sur-Orge, France). 
( $4.7 \mathrm{mmol} / \mathrm{l})$ was infused into a small vein on the internal curvature of the caecum, at a rate of $50 \mu \mathrm{l} / \mathrm{min}$. Dilution of the marker in the vein draining the whole caecum (without collateral circulation to ileum or colon) affords determination of the caecal blood flow. Blood was withdrawn from the caecal vein and the abdominal aorta. The blood was placed in microfuge tubes containing heparin and centrifuged at $10000 \mathrm{~g}$ for $2 \mathrm{~min}$. Plasma samples were stored at $4^{\circ} \mathrm{C}$ for mineral analysis.

After blood sampling, the caecum, complete with contents, was removed and weighed (total caecal weight). Duplicate samples were collected into $2 \mathrm{ml}$ microfuge tubes that were immediately stored at $-20^{\circ} \mathrm{C}$. The caecal walls were flushed clean with ice-cold saline, blotted on filter paper and weighed (caecal wall weight). Supernatant fractions of the digestive contents were obtained by centrifuging one of the two microfuge tubes at $20000 \mathrm{~g}$ for $10 \mathrm{~min}$ at $4^{\circ} \mathrm{C}$.

\section{Analytical procedures}

SCFA were measured by GLC on aliquots of supernatant fractions of caecal contents as previously described (Demigné et al. 1980). Ca and Mg were determined on the plasma, caecal supernatant fractions (soluble), urine, and, after mineralization $\left(0.8 \mathrm{M}-\mathrm{HCl}, 12 \mathrm{~h}\right.$ at $\left.800^{\circ} \mathrm{C}\right)$, on the untreated caecal samples (total) and faecal materials. After an adequate dilution, mineral concentrations were measured by atomic absorption spectrophotometry (Perkin-Elmer 400; Perkin-Elmer, Norwalk, CT, USA) at wavelengths of $422 \mathrm{~nm}(\mathrm{Ca})$ and $285 \mathrm{~nm}(\mathrm{Mg})$.

\section{Calculation and data analysis}

The entire caecal content was calculated as: caecal concentration $(\mu \mathrm{mol} / \mathrm{ml}) \times$ caecal water $(\mathrm{ml})$; and caecal absorption as (caecal vein)-(artery) difference $(\mu \mathrm{mol} / \mathrm{ml}$ plasma $) \times$ caecal plasma flow $(\mathrm{ml} / \mathrm{min})$. For the determination of digestive balance, food and faeces samples of each rat collected during $5 \mathrm{~d}$ were homogenized before mineral analysis. Intake of Ca via the drinking water was considered to be negligible $(<0.5 \mathrm{mg} / \mathrm{l})$ compared with that from the diet and was not considered.

Values are given as values with their standard errors and, where appropriate, significance of differences between mean values was determined by ANOVA and multiple range comparisons by Fisher's least-significant difference procedures. Values of $P<0.05$ were considered significant.

\section{Results}

Food intake, body weight and caecal fermentation variables

Neither the daily food intake nor the body-weight gain were significantly different between the experimental groups. As expected, the presence of fermentable carbohydrates in the diets resulted in an enlargement of the caecum and lowered caecal pH compared with the control group (Table 2). The results of the rats fed the combination of the carbohydrates were statistically similar to those of the rats fed the carbohydrates separately. With regard to the SCFA, fermentable carbohydrate ingestion increased significantly $(P<0.05)$ the molar concentration of SCFA in the caecum, particularly in the RS and inulin $+\mathrm{RS}$ groups (Table 3 ). The effect of fermentable carbohydrates on the production of SCFA became more marked when the results were expressed as the amount of SCFA per caecum, RS group exhibiting the greatest produced amount of SCFA. The profile of SCFA was changed in the caecum in the presence of fermentable carbohydrates. Thus, the molar proportions of propionate and butyrate were raised at the expense of acetate in rats fed inulin or RS respectively. In rats fed the combination of fermentable carbohydrates, both propionate and butyrate molar proportions were increased (Table 3).

\section{Caecal absorption of calcium and magnesium}

Table 4 shows that caecal fermentation of the tested carbohydrates increased significantly the solubility of $\mathrm{Ca}$ and $\mathrm{Mg}$ (4-fold for $\mathrm{Ca}$ and 2-fold for $\mathrm{Mg}$ ) in the caecum. This has as consequence of increasing the bioavailability of these two minerals. Moreover, rats fed fermentable carbohydrates had a higher caecal blood flow than the control group. Consequently, the caecal $\mathrm{Ca}$ and $\mathrm{Mg}$ absorption increased significantly in the rats fed fermentable carbohydrates. The rats fed the blend of both fermentable carbohydrates had a higher soluble caecal concentration of both $\mathrm{Ca}$ and $\mathrm{Mg}$ accompanied by a higher caecal $\mathrm{Mg}$ absorption compared with the rats fed with either of the studied fermentable carbohydrates separately (Table 4). However, the difference in the caecal $\mathrm{Mg}$ absorption was not statistically significant.

Table 2. Effects of dietary conditions on daily food intake, daily weight gain and variables of caecal development* (Mean values with their standard errors for eight rats per group)

\begin{tabular}{|c|c|c|c|c|c|c|c|c|c|c|}
\hline \multirow[b]{2}{*}{ Diets } & \multicolumn{2}{|c|}{$\begin{array}{l}\text { Daily food } \\
\text { intake (g) }\end{array}$} & \multicolumn{2}{|c|}{$\begin{array}{l}\text { Daily weight } \\
\text { gain }(\mathrm{g})\end{array}$} & \multicolumn{2}{|c|}{$\begin{array}{l}\text { Caecum } \\
\text { weight }(\mathrm{g})\end{array}$} & \multicolumn{2}{|c|}{$\begin{array}{l}\text { Wall caecum } \\
\text { weight }(\mathrm{g})\end{array}$} & \multicolumn{2}{|c|}{$\mathrm{pH}$} \\
\hline & Mean & SE & Mean & SE & Mean & SE & Mean & SE & Mean & SE \\
\hline Fibre-free & $22 \cdot 2^{a}$ & $1 \cdot 2$ & $6 \cdot 06^{a}$ & 0.44 & $2 \cdot 54^{a}$ & 0.17 & $0 \cdot 64^{a}$ & 0.02 & $7 \cdot 01^{\mathrm{a}}$ & $0 \cdot 10$ \\
\hline Inulin & $21 \cdot 0^{a}$ & 0.9 & $5 \cdot 58^{a}$ & 0.36 & $5 \cdot 33^{b}$ & 0.28 & $1 \cdot 21^{b}$ & 0.04 & $5 \cdot 60^{\mathrm{b}}$ & 0.07 \\
\hline Resistant starch & $22 \cdot 5^{a}$ & 0.9 & $6 \cdot 03^{a}$ & 0.57 & $6.03^{b}$ & 0.57 & $1 \cdot 28^{b}$ & 0.09 & $5 \cdot 77^{\mathrm{b}}$ & 0.06 \\
\hline Inulin+resistant starch & $22 \cdot 2^{a}$ & $1 \cdot 0$ & $5 \cdot 50^{\mathrm{a}}$ & 0.32 & $5 \cdot 12^{b}$ & 0.28 & $1 \cdot 23^{b}$ & 0.04 & $5 \cdot 62^{b}$ & 0.06 \\
\hline
\end{tabular}

${ }^{a, b}$ Mean values within a column with unlike superscript letters were significantly different $(P<0.05)$.

${ }^{*}$ For details of diets and procedures, see Table 1 and p. 480. 
Table 3. Effects of dietary conditions on variables of caecal fermentations* (Mean values with their standard errors for eight rats per group)

\begin{tabular}{|c|c|c|c|c|c|c|c|c|c|c|c|}
\hline \multirow[b]{2}{*}{ Diets } & \multicolumn{2}{|c|}{$\begin{array}{l}\text { [Acetate] } \\
\quad(\mathrm{mm})\end{array}$} & \multicolumn{2}{|c|}{$\begin{array}{l}\text { [Propionate] } \\
\quad(\mathrm{mm})\end{array}$} & \multicolumn{2}{|c|}{$\begin{array}{l}\text { [Butyrate] } \\
\text { (mM) }\end{array}$} & \multicolumn{2}{|c|}{$\begin{array}{l}\text { [Total } \\
\text { SCFA] } \\
(\mathrm{mm})\end{array}$} & \multicolumn{2}{|c|}{$\begin{array}{c}\text { Total SCFA } \\
\text { ( } \mu \mathrm{mol} / \\
\text { caecum })\end{array}$} & \multirow{2}{*}{$\begin{array}{c}\text { Molar ratio } \\
\text { acetate:propionate:butyrate }\end{array}$} \\
\hline & Mean & SE & Mean & SE & Mean & SE & Mean & SE & Mean & SE & \\
\hline Fibre-free & $71.9^{a}$ & $5 \cdot 5$ & $27 \cdot 3^{a}$ & $1 \cdot 6$ & $9 \cdot 8^{a}$ & 0.5 & $109^{a}$ & 6 & $164^{\mathrm{a}}$ & 9 & $66: 25: 9$ \\
\hline Inulin & $68 \cdot 5^{\mathrm{a}}$ & $5 \cdot 3$ & $48 \cdot 0^{\mathrm{b}}$ & 1.9 & $20 \cdot 6^{\mathrm{b}}$ & 0.7 & $137^{\mathrm{b}}$ & 6 & $440^{b}$ & 18 & $50: 35: 15$ \\
\hline Resistant starch & $104 \cdot 2^{c}$ & 6.9 & $42 \cdot 8^{b}$ & 2.0 & $39 \cdot 1^{c}$ & $1 \cdot 4$ & $186^{c}$ & 9 & $626^{c}$ & 26 & $56: 23: 21$ \\
\hline Inulin+resistant starch & $100 \cdot 4^{c}$ & $6 \cdot 1$ & $56 \cdot 0^{c}$ & $2 \cdot 8$ & $36 \cdot 7^{\mathrm{C}}$ & $1 \cdot 7$ & $193^{c}$ & 11 & $575^{\mathrm{c}}$ & 23 & $52: 29: 19$ \\
\hline
\end{tabular}

SCFA, short-chain fatty acid.

a,b,c Mean values within a column with unlike superscript letters were significantly different $(P<0.05)$.

${ }^{*}$ For details of diets and procedures, see Table 1 and p. 480.

Table 4. Effects of dietary conditions on caecal concentration and absorption of calcium and magnesium* (Mean values with their standard errors for eight rats per group)

\begin{tabular}{|c|c|c|c|c|c|c|c|c|c|c|c|c|c|c|}
\hline \multirow[b]{2}{*}{ Diets } & \multicolumn{2}{|c|}{$\begin{array}{c}\text { Total caecal } \\
(\mathrm{mm})\end{array}$} & \multicolumn{2}{|c|}{$\begin{array}{c}\text { Soluble } \\
\text { caecal (mM) }\end{array}$} & \multicolumn{2}{|c|}{$\begin{array}{c}\text { Total } \\
\text { caecal pool } \\
(\mu \mathrm{mol})\end{array}$} & \multicolumn{2}{|c|}{$\begin{array}{c}\text { Soluble } \\
\text { caecal pool } \\
(\mu \mathrm{mol})\end{array}$} & \multicolumn{2}{|c|}{$\begin{array}{l}\text { Caecal } \\
\text { solubility } \\
\text { (\% of total) }\end{array}$} & \multicolumn{2}{|c|}{$\begin{array}{l}\text { Caecal blood } \\
\text { flow }(\mathrm{ml} / \mathrm{min})\end{array}$} & \multicolumn{2}{|c|}{$\begin{array}{l}\text { Caecal } \\
\text { absorption } \\
\text { ( } \mu \mathrm{mol} / \mathrm{min})\end{array}$} \\
\hline & Mean & SE & Mean & SE & Mean & $\mathrm{SE}$ & Mean & $\mathrm{SE}$ & Mean & SE & Mean & SE & Mean & SE \\
\hline \multicolumn{15}{|l|}{ Calcium } \\
\hline Fibre-free & $488^{\mathrm{C}}$ & 28 & $16 \cdot 9^{a}$ & 0.9 & $873^{a}$ & 39 & $25 \cdot 4^{\mathrm{a}}$ & $2 \cdot 7$ & $2 \cdot 91^{\mathrm{a}}$ & 0.36 & $1 \cdot 10^{\mathrm{a}}$ & 0.06 & $0.14^{\mathrm{a}}$ & 0.03 \\
\hline Inulin & $230^{a}$ & 15 & $28 \cdot 0^{\mathrm{b}}$ & 1.5 & $1029^{a}$ & 68 & $96 \cdot 4^{\mathrm{b}}$ & $6 \cdot 2$ & $9 \cdot 37^{\mathrm{b}}$ & 1.03 & $1.80^{\mathrm{b}}$ & 0.08 & $0.56^{\mathrm{b}}$ & 0.06 \\
\hline Resistant starch & $278^{a, b}$ & 20 & $30 \cdot 4^{b}$ & $2 \cdot 2$ & $1269^{\mathrm{b}}$ & 65 & $102 \cdot 0^{\mathrm{b}}$ & 7.3 & $8 \cdot 04^{b}$ & 0.67 & $1.90^{\mathrm{b}}$ & 0.10 & $0.59^{b}$ & 0.07 \\
\hline Inulin+resistant starch & $309^{b}$ & 18 & $38 \cdot 6^{\mathrm{c}}$ & 2.4 & $1203^{b}$ & 36 & $115 \cdot 0^{\mathrm{b}}$ & $6 \cdot 8$ & $9 \cdot 56^{\mathrm{b}}$ & 1.09 & $1.92^{b}$ & 0.08 & $0.54^{b}$ & 0.06 \\
\hline \multicolumn{15}{|l|}{ Magnesium } \\
\hline Fibre-free & $101^{\mathrm{b}}$ & 5 & $15 \cdot 0^{\mathrm{a}}$ & 0.8 & $192^{\mathrm{a}}$ & 9 & $22 \cdot 5^{\mathrm{a}}$ & $1 \cdot 2$ & $11 \cdot 7^{\mathrm{a}}$ & 0.8 & $1 \cdot 10^{\mathrm{a}}$ & 0.06 & $0.12^{\mathrm{a}}$ & 0.01 \\
\hline Inulin & $49^{\mathrm{a}}$ & 3 & $12 \cdot 2^{\mathrm{a}}$ & $1 \cdot 1$ & $224^{\mathrm{b}}$ & 10 & $42 \cdot 0^{\mathrm{b}}$ & $3 . \overline{5}$ & $18 \cdot 8^{\mathrm{b}}$ & 1.6 & $1.80^{\mathrm{b}}$ & 0.08 & $0.43^{b}$ & 0.03 \\
\hline Resistant starch & $49^{a}$ & 2 & $13 \cdot 8^{a}$ & 1.0 & $231^{\mathrm{b}}$ & 9 & $46 \cdot 5^{\mathrm{b}}$ & 4.9 & $20 \cdot 1^{\mathrm{b}, \mathrm{c}}$ & $1 \cdot 7$ & $1.90^{\mathrm{b}}$ & 0.10 & $0.34^{b}$ & 0.03 \\
\hline Inulin+resistant starch & $52^{a}$ & 3 & $18 \cdot 3^{\mathrm{b}}$ & 0.9 & $227^{\mathrm{b}}$ & 11 & $54 \cdot 2^{\mathrm{b}}$ & 1.5 & $23 \cdot 9^{c}$ & $2 \cdot 6$ & $1.92^{b}$ & 0.08 & $0.52^{b}$ & 0.04 \\
\hline
\end{tabular}

a,b,c Mean values within a column with unlike superscript letters were significantly different $(P<0.05)$.

${ }^{*}$ For details of diets and procedures, see Table 1 and p. 480.

Table 5. Effects of dietary conditions on the digestive and total balances of calcium and magnesium* (Mean values with their standard errors for eight rats per group)

\begin{tabular}{|c|c|c|c|c|c|c|c|c|c|c|c|c|}
\hline \multirow[b]{2}{*}{ Diets } & \multicolumn{2}{|c|}{ Intake (mg/d) } & \multicolumn{2}{|c|}{$\begin{array}{l}\text { Faecal } \\
\text { excretion } \\
\text { (mg/d) }\end{array}$} & \multicolumn{2}{|c|}{$\begin{array}{l}\text { Absorption } \\
\text { (mg/d) }\end{array}$} & \multicolumn{2}{|c|}{$\begin{array}{c}\text { Absorption } \\
\text { (\% intake) }\end{array}$} & \multicolumn{2}{|c|}{$\begin{array}{l}\text { Urinary excretion } \\
(\mathrm{mg} / \mathrm{d})\end{array}$} & \multicolumn{2}{|c|}{$\begin{array}{l}\text { Net balance } \\
(\mathrm{mg} / \mathrm{d})\end{array}$} \\
\hline & Mean & SE & Mean & SE & Mean & SE & Mean & SE & Mean & SE & Mean & SE \\
\hline \multicolumn{13}{|l|}{ Calcium } \\
\hline Fibre-free & $164^{a}$ & 10 & $126^{\mathrm{d}}$ & 5 & $38^{\mathrm{a}}$ & 2 & $23^{a}$ & 2 & $4 \cdot 69^{a}$ & 0.53 & $33 \cdot 3^{a}$ & $2 \cdot 1$ \\
\hline Inulin & $162^{a}$ & 9 & $102^{b}$ & 3 & $60^{\mathrm{b}}$ & 3 & $37^{\mathrm{b}}$ & 2 & $9 \cdot 00^{\mathrm{b}}$ & 0.76 & $51 \cdot 0^{\mathrm{b}}$ & $3 \cdot 2$ \\
\hline Resistant starch & $166^{a}$ & 12 & $114^{\mathrm{C}}$ & 4 & $52^{b}$ & 3 & $31^{\mathrm{b}}$ & 4 & $9 \cdot 18^{b}$ & 0.98 & $42 \cdot 8^{b}$ & 2.4 \\
\hline Inulin+resistant starch & $160^{a}$ & 9 & $75^{\mathrm{a}}$ & 4 & $85^{\mathrm{C}}$ & 5 & $53^{c}$ & 2 & $12 \cdot 71^{\mathrm{c}}$ & 0.87 & $72 \cdot 3^{c}$ & $4 \cdot 1$ \\
\hline \multicolumn{13}{|l|}{ Magnesium } \\
\hline Fibre-free & $20 \cdot 8^{\mathrm{a}}$ & 1.1 & $13 \cdot 6^{\mathrm{b}}$ & 0.4 & $7 \cdot 2^{\mathrm{a}}$ & 0.4 & $35^{\mathrm{a}}$ & 2 & $3 \cdot 80^{a}$ & 0.27 & $3 \cdot 4^{\mathrm{a}}$ & 0.2 \\
\hline Inulin & $22 \cdot 4^{\mathrm{a}}$ & 1.2 & $9 \cdot 7^{\mathrm{a}}$ & 0.9 & $12 \cdot 7^{\mathrm{b}}$ & 0.7 & $57^{\mathrm{b}}$ & 3 & $7 \cdot 52^{b}$ & 0.28 & $5 \cdot 2^{b}$ & 0.3 \\
\hline Resistant starch & $23 \cdot 0^{a}$ & $1 \cdot 0$ & $11 \cdot 1^{\mathrm{a}}$ & 0.7 & $11.9^{b}$ & 0.6 & $52^{b}$ & 5 & $7 \cdot 52^{b}$ & 0.53 & $4 \cdot 9^{\mathrm{b}}$ & 0.2 \\
\hline Inulin+resistant starch & $21 \cdot 9^{a}$ & 1.1 & $7 \cdot 9^{a}$ & 0.6 & $14 \cdot 0^{\mathrm{b}}$ & 0.7 & $64^{\mathrm{b}}$ & 3 & $8 \cdot 10^{b}$ & 0.60 & $5 \cdot 9^{b}$ & 0.8 \\
\hline
\end{tabular}

a,b,c Mean values within a column with unlike superscript letters were significantly different $(P<0.05)$.

${ }^{*}$ For details of diets and procedures, see Table 1 and p. 480.

Intestinal absorption, balance and plasma level of calcium

As shown in Table 5, the daily intake of $\mathrm{Ca}$ was similar, whereas daily faecal excretion of $\mathrm{Ca}$ was significantly different between the four studied groups. This is because intestinal absorption of $\mathrm{Ca}(\mathrm{mg} / \mathrm{d})$ was significantly increased in the groups fed the fermentable carbohydrates compared with the control group. Moreover, this increase was significantly higher in the group fed the blend of both fermentable carbohydrates than that observed in rats fed one of the studied fermentable carbohydrates, separately (Table 5). Urinary $\mathrm{Ca}$ excretion was also increased in the 
Table 6. Effects of dietary fibre conditions on the plasma content of calcium and magnesium*

(Mean values with their standard errors for eight rats per group)

\begin{tabular}{|c|c|c|c|c|}
\hline \multirow{2}{*}{ Diets } & \multicolumn{2}{|c|}{$\begin{array}{c}\text { Plasma Ca } \\
\quad(\mathrm{mm})\end{array}$} & \multicolumn{2}{|c|}{$\begin{array}{l}\text { Plasma Mg } \\
\quad(\mathrm{mm})\end{array}$} \\
\hline & Mean & SE & Mean & SE \\
\hline Fibre-free & $2 \cdot 77^{\mathrm{a}}$ & 0.05 & $0.74^{a}$ & 0.04 \\
\hline Inulin & $2 \cdot 68^{a}$ & 0.04 & $0.78^{a}$ & 0.03 \\
\hline Resistant starch & $2 \cdot 83^{a}$ & 0.07 & $0 \cdot 84^{a, b}$ & 0.04 \\
\hline Inulin+resistant starch & $2.92^{\mathrm{a}}$ & 0.08 & $0.95^{\mathrm{b}}$ & 0.05 \\
\hline
\end{tabular}

${ }^{a, b}$ Mean values within a column with unlike superscript letters were significantly different $(P<0.05)$.

*For details of diets and procedures, see Table 1 and p. 480.

rats fed fermentable carbohydrates separately and this increase was significantly more important in the group fed the blend of both fermentable carbohydrates than in the other groups. In spite of this increase in $\mathrm{Ca}$ urinary excretion, $\mathrm{Ca}$ retention (overall balance) significantly increased in the rats fed fermentable carbohydrates and this increase was the most important in the group fed the blend of both fermentable carbohydrates (Table 5). Finally, the ingestion of the tested carbohydrates, separately or in combination, was without effect on plasma $\mathrm{Ca}$ level (Table 6).

\section{Intestinal absorption, balance and plasma level of magnesium}

As shown in Table 5, daily intake of $\mathrm{Mg}$ was similar, but daily faecal excretion of $\mathrm{Mg}$ was significantly decreased in the three fermentable carbohydrate groups compared with the control group. In accordance with this, the intestinal absorption of $\mathrm{Mg}(\mathrm{mg} / \mathrm{d})$, the excretion of $\mathrm{Mg}$ in urine and the retention of $\mathrm{Mg}$ (overall balance) were significantly increased $(P<0.05)$ in the groups fed the fermentable carbohydrates compared with the control group. However, these increases were not significantly different between the group fed the blend of both fermentable carbohydrates and those fed one of the studied fermentable carbohydrates separately (Table 5). In addition, plasma $\mathrm{Mg}$ level in the rats fed the fermentable carbohydrates singly was not different from that of the control group, whereas it was significantly increased $(P<0.05)$ in the rats fed the blend of both fermentable carbohydrates, compared with the control and inulin groups (Table 6).

\section{Discussion}

It has often been reported that vegetable products, rich in indigestible dietary carbohydrates, may affect the bioavailability of minerals. Impairment of $\mathrm{Ca}$ and $\mathrm{Mg}$ absorption by dietary fibre is traditionally ascribed to the phytic acid content or to the uronic acid content of fibre fractions (McCance \& Widdowson, 1942; Reinhold et al. 1976). However, when fermentable carbohydrates like RS and inulin were ingested, there was no decrease, but an increase in $\mathrm{Ca}$ and $\mathrm{Mg}$ absorption. The beneficial effects of fermentable carbohydrates on mineral absorption in rats were reported for the first time in our laboratory in 1977 (Rayssiguier \& Rémésy, 1977). This beneficial effect is now well documented with different fermentable carbohydrates in many nutritional conditions in animals (Demigné et al. 1980; Ohta et al. 1994, 1995, 1996; Delzenne et al. 1995; Campbell et al. 1997; Yanahira et al. 1997) and in some studies with human subjects (Van den Heuvel et al. 1999; Coudray et al. 1997a, Tahiri et al. 2001). However, such effects are dependent on the type of fermentable carbohydrates (dose, structure and relative molecular mass) and on the duration of the experiment (Lajvardi et al. 1993; Campbell et al. 1997). The aim of the present study was to investigate the potential synergistic effect of a blend of two different fermentable carbohydrates on the fermentation variables and on the caecal and the apparent intestinal absorption of $\mathrm{Ca}$ and $\mathrm{Mg}$ in rats. Our results showed clearly that a combination of different carbohydrates had synergistic effects on intestinal $\mathrm{Ca}$ and $\mathrm{Mg}$ absorption and on plasma $\mathrm{Mg}$ level in rats.

The caecum of the rat is the main site of degradation of fermentable carbohydrates. As expected, our present results, obtained in a relatively short-term experiment lasting 3 weeks, indicate that both inulin and RS are extensively fermented in the rat caecum leading to significant changes in caecum content and wall weights, SCFA production and caecal lumen $\mathrm{pH}$. The ingestion of fermentable carbohydrates induced caecal development and caecal weight rise was at least 2-fold greater than in the control group, resulting in a greater exchange surface area in the caecum. This development of the caecal wall is due to a combination effect of both hypertrophy and hyperplasia (Rémésy et al. 1993; Levrat et al. 1991a). Caecal SCFA concentration was the most important in the group fed the blend of inulin and $\mathrm{RS}$, which may reflect higher activity of fermentation in these rats than in those received one of the studied fermentable carbohydrates singly. Similar results have been reported by Topping et al. 1985. They observed that concentrations of SCFA in caecal fluid did not differ between rats fed gum arabic or cellulose, but were raised in rats fed the mixture. SCFA play an important role in the enhancement of caecal mineral absorption (Scharrer \& Lutz, 1990, 1992; Trinidad et al. 1999). The acidic caecal $\mathrm{pH}$ resulting from ingestion of the fermentable carbohydrate diets is caused by the greater level of total SCFA production (Younes et al. 1996; Le Blay et al. 1999). This reduction in caecal $\mathrm{pH}$ leads to greater solubilization of $\mathrm{Mg}$ and $\mathrm{Ca}$ so that the biologically available concentration of these minerals is increased (Lutz et al. 1991; Rémésy et al. 1993). Indeed, it was shown that the reduction in the ileal $\mathrm{pH}$ was inversely related to apparent absorption of $\mathrm{Mg}$ (Heijnen et al. 1993). Another possible hypothesis is that SCFA contribute directly to the enhancement of $\mathrm{Mg}$ and $\mathrm{Ca}$ absorption via a cation exchange mechanism (Trinidad et al. 1996, 1999). SCFA in a protonated form are absorbed across the apical membrane and undergo dissociation within the intracellular environment. The increased intracellular $\mathrm{H}^{+}$ are then secreted from the cell into the lumen in exchange for $\mathrm{Mg}^{2+}$ or one $\mathrm{Ca}^{2+}$. SCFA may also directly influence intestinal mineral absorption by forming a lower charge complex with $\mathrm{Mg}$ or $\mathrm{Ca}$ which can across the cell membrane (Lutz et al. 1991; Trinidad et al. 1996, 1999). Finally, SCFA 
may also responsible for the rise in caecal blood flow and may thus increase the overall mineral input, as reported in the colon (Kvietys \& Granger, 1981).

$\mathrm{Ca}$ and $\mathrm{Mg}$ are absorbed from both the small and the large intestine, which includes the caecum. According to our results, the fermentable carbohydrates ingestion resulting in the lowering of lumen $\mathrm{pH}$ led to an increase in the soluble mineral fractions in the caecum (4-fold for $\mathrm{Ca}$ and 2-fold for $\mathrm{Mg}$ ). Again, the combination of both studied fermentable carbohydrates was more effective in increasing soluble $\mathrm{Ca}$ and $\mathrm{Mg}$ concentrations in the caecum than each fermentable carbohydrates fed singly. This is very important, because the solubility of a mineral is a major determinant for its absorption. Moreover, the caecal blood flow was significantly increased in the rats receiving the fermentable carbohydrates compared with the control group. This phenomenon has been already observed (Demigné et al. 1989). Consequently, the process of caecal absorption of $\mathrm{Ca}$ and $\mathrm{Mg}$ was enhanced in parallel with the dietary intake of fermentable carbohydrates, and large amounts of $\mathrm{Ca}$ and $\mathrm{Mg}$ were absorbed via the caecum in the rats fed the fermentable carbohydrate diets (3- to 4-fold) compared with the control diet. This is in agreement with the increase in SCFA production and the increase in the higher solubility of $\mathrm{Ca}$ and $\mathrm{Mg}$ observed in the rats fed the fermentable carbohydrates in the present experiment. The rats fed the blend of fermentable carbohydrates presented the higher $\mathrm{Ca}$ and $\mathrm{Mg}$ soluble caecal concentration with a high $\mathrm{Mg}$ caecal absorption rate, which reflects a potential synergistic effect between the two fermentable carbohydrates.

The results of the present study showed that apparent intestinal absorption of $\mathrm{Ca}$ and $\mathrm{Mg}$ increased significantly $(P<0.05)$ in rats fed the fermentable carbohydrates separately. Interestingly, the increase in apparent intestinal absorption of $\mathrm{Ca}$ and $\mathrm{Mg}$ was more important in the rats fed with the blend of two studied fermentable carbohydrates, which reached a significant threshold when the $\mathrm{Ca}$ absorption was expressed in both $\mathrm{mg} / \mathrm{d}$ and in percentage terms. This is in agreement with the results of caecal mineral absorption. In the present study, feeding rats with fermentable carbohydrates had a comparable effect on the intestinal absorption of $\mathrm{Ca}$ and $\mathrm{Mg}$. Thus, increasing divalent cation absorption in the large intestine did not seem to be accompanied by a lower absorption of these cations in the small intestine under the conditions of the present study.

The improvement of apparent intestinal $\mathrm{Ca}$ absorption by the fermentable carbohydrates singly and in combination was not accompanied by significant modifications in plasma $\mathrm{Ca}$ levels. Such results are in accordance with previous observations (Levrat et al. 1991a; Delzenne et al. 1995; Lopez et al. 1998, 2000). Moreover, the increase in apparent intestinal $\mathrm{Mg}$ absorption by the fermentable carbohydrates, fed singly, was not accompanied by significant modifications in plasma $\mathrm{Mg}$ levels, but fermentable carbohydrates in combination led to significantly $(P<0.05)$ higher plasma $\mathrm{Mg}$ levels than in the control or the inulin groups. Indeed, Ca blood homeostasis is efficiently controlled, whereas that of $\mathrm{Mg}$ is less tightly controlled. In keeping with this, many reports in the literature indicate that a high intake of dietary $\mathrm{Mg}$ or an improvement in intestinal $\mathrm{Mg}$ absorption are generally accompanied by an increase in plasma Mg levels (Rayssiguier \& Rémésy, 1977; Navas \& Cordova, 1996; Coudray et al. 1997b).

In conclusion, the feeding of inulin or RS significantly $(P<0.05)$ increased the apparent intestinal absorption of $\mathrm{Ca}$ and $\mathrm{Mg}$ in rats without significant change in their plasma levels. Interestingly, the combination of these different fermentable carbohydrates showed significant synergistic effects on intestinal $\mathrm{Ca}$ absorption and on plasma $\mathrm{Mg}$ levels in rats. These results are relevant because foods are very complex and may contain many types of fermentable carbohydrates in each meal. The non-purified vegetable products have the double interest of being both rich in minerals and an important source of fermentable carbohydrates which can enhance the intestinal absorption of these minerals. Further studies with other types of fermentable carbohydrates deserve to be carried out to extend these findings.

\section{Acknowledgements}

The authors wish to thank Jean Claude Tressol and Pierre Lamby for their technical assistance.

\section{References}

Allen LH (1982) Calcium bioavailability and absorption: a review. American Journal of Clinical Nutrition 35, 783-808.

Andrieux C, Gadelle D, Leprince C \& Sacquet E (1989) Effects of some poorly digestible carbohydrates on bile acid bacterial transformation in the rat. British Journal of Nutrition 62, 103-119.

Brink EJ \& Beynen AC (1992) Nutrition and magnesium absorption: a review. Progress in Food and Nutritional Science 16, $125-162$.

Campbell JM, Fahey GC \& Wolf BW (1997) Selected indigestible oligosaccharides affect large bowel mass, cecal and fecal shortchain fatty acids, $\mathrm{pH}$ and microflora in rats. Journal of Nutrition 127, 130-136.

Coudray C, Bellanger J, Castiglia-Delavaud C, Rémésy C, Vermorel M \& Rayssiguier Y (1997a) Effect of soluble and insoluble dietary fiber supplementation in healthy young men: apparent absorption and balance of calcium, magnesium, iron and zinc. European Journal of Clinical Nutrition 51, 375-380.

Coudray C, Pépin D, Tressol JC, Bellanger J \& Rayssiguier Y (1997b) Study of magnesium bioavailability using magnesium stable isotopes and inductively-coupled plasma - mass spectrometry technique in rat: simple and double labelling approaches. British Journal of Nutrition 77, 957-970.

Coudray C \& Fairweather-Tait SJ (1998) Do oligosaccharides affect intestinal absorption of calcium in humans? American Journal of Clinical Nutrition 68, 921-923.

de Deckere EAM, Kloots WJ \& Van Amelsvoort JMM (1993) Resistant starch decreases serum total cholesterol and triglycerol concentrations in rats. Journal of Nutrition 123, 2142-2151.

Delzenne N, Aertssens J, Verplaetse H, Roccaro M \& Roberfroid M (1995) Effect of fermentable fructo-oligosaccharides on mineral, nitrogen and energy digestive balance in the rat. Life Sciences 57, 1579-1587.

Demigné C, Rémésy C \& Rayssiguier Y (1980) Effect of fermentable carbohydrates on volatile fatty acids, ammonia and mineral absorption in the rat caecum. Reproduction Nutrition \& Développement 20, 1351-1359.

Demigné C \& Rémésy C (1985) Stimulation of absorption of volatile fatty acids and minerals in the cecum of rats adapted to a very high fiber diet. Journal of Nutrition 115, 53-60. 
Demigné C, Levrat MA \& Rémésy C (1989) Effects of feeding fermentable carbohydrates on the cecal concentrations of minerals and their fluxes between the cecum and blood plasma in the rat. Journal of Nutrition 119, 1625-1630.

Ebel H \& Gunther T (1980) Magnesium metabolism: a review. Journal of Clinical Chemistry and Clinical Biochemistry 18, 257-270.

Gibson GR, Beatty ER, Wang X \& Cummings JH (1995) Selective stimulation of bifidobacteria in the human colon by oligofructose and inulin. Gastroenterology 108, 975-982.

Hardwick LL, Jones MR, Brautbar N \& Lee DB (1990) Site and mechanism of intestinal magnesium absorption. Minerals and Electrolyte Metabolism 16, 174-180.

Heijnen AM, Brink EJ, Lemmens AG \& Beynen AC (1993) Ileal $\mathrm{pH}$ and apparent absorption of magnesium in rats fed on diets containing either lactose or lactulose. British Journal of Nutrition 70, 747-756.

Jackson KG, Taylor GRJ, Clohessy AM \& Williams CM (1999) The effect of the daily intake of inulin on fasting lipid, insulin and glucose concentrations in middle-aged men and women. British Journal of Nutrition 82, 23-30.

Kayne LH \& Lee DB (1993) Intestinal magnesium absorption. Minerals and Electrolyte Metabolism 19, 210-217.

Kvietys PR \& Granger DN (1981) Effect of volatile fatty acids on blood flow and oxygen uptake by the dog colon. Gastroenterology 80, 962-969.

Kruse HP, Kleessen B \& Blaut M (1999) Effects of inulin on faecal bifidobacteria in human subjects. British Journal of Nutrition $\mathbf{8 2}$, 375-382.

Lajvardi A, Mazarin GI, Gillespie B, Satchithanadam S \& Calvert RJ (1993) Starches of varied digestibilities modify intestinal function in rats. Journal of Nutrition 123, 2059-2066.

Le Blay G, Michel C, Blottiere HM \& Cherbut C (1999) Prolonged intake of fructo-oligosaccharides induces a short-term elevation of lactic acid-producing bacteria and a persistent increase in cecal butyrate in rats. Journal of Nutrition 129, 2231-2235.

Levrat MA, Behr SR, Rémésy C \& Demigné C (1991a) Effects of soybean fiber on cecal digestion in rats previously adapted to a fiber-free diet. Journal of Nutrition 121, 672-678.

Levrat MA, Rémésy C \& Demigné C (1991b) High propionic acid fermentations and mineral accumulation in the cecum of rats adapted to different levels of inulin. Journal of Nutrition 121, $1730-1737$.

Lopez WH, Coudray C, Bellanger J, Younes H, Demigné C \& Rémésy C (1998) Intestinal fermentation lessens the inhibitory effects of phytic acid on mineral utilisation in rats. Journal of Nutrition 128, 1192-1198.

Lopez WH, Coudray C, Bellanger J, Levrat-Verny MA, Demigné C, Rayssiguier Y \& Rémésy C (2000) Resistant starch improves mineral assimilation in rats adapted to a wheat bran diet. Intestinal fermentation lessens the inhibitory effects of phytic acid on mineral utilisation in rats. Nutritional Research 20, 141-155.

Lutz T, Wurmli R \& Scharrer E (1991) Short-chain fatty acids stimulate magnesium absorption by the colon. In Magnesium A Relevant Ion, pp. 131-137 [B Lasserre and J Durlach, editors]. London: John Libbey.

McCance R \& Widdowson E (1942) Mineral metabolism of healthy adults on white and brown bread dietaries. Journal of Physiology 101, 44-85.

Morais MB, Feste A, Miller RG \& Lifschitz CH (1996) Effect of resistant and digestible starch on intestinal absorption of calcium, iron and zinc in infant pigs. Pediatric Research 39, 872-876.

Navas FJ \& Cordova A (1996) Effect of magnesium supplementation and training on magnesium tissue distribution in rats. Biological Trace Element Research 53, 137-145.

Ohta A, Ohtuki M, Takizawa T, Inaba H, Adachi T \& Kimura S
(1994) Effects of fructooligosaccharides on the absorption of magnesium and calcium by cecectomized rats. International Journal of Vitamin and Nutritional Research 64, 316-323.

Ohta A, Ohtsuki M, Baba S, Adachi T, Sakata T \& Sakaguchi EI (1995) Calcium and magnesium absorption from the colon and rectum are increased in rats fed fructooligosaccharides. Journal of Nutrition 125, 2417-2424.

Ohta A, Baba S, Ohtsuki M, Taguchi A \& Adachi T (1996) Prevention of coprophagy modifies magnesium absorption in rats fed with fructo-oligosaccharides. British Journal of Nutrition 75, 775-784.

Rayssiguier Y \& Rémésy C (1977) Magnesium absorption in the caecum of rats related to volatile fatty acids production. Annuelle de Recherche Vétérinaire 8, 105-110.

Reinhold JG, Faradji B, Abadi P \& Ismail-Beigi F (1976) Decreased absorption of calcium, magnesium, zinc and phosphorus by humans due to increased fiber and phosphorus consumption as wheat bread. Journal of Nutrition 106, 493-503.

Rémésy C, Levrat MA, Gamet L \& Demigné C (1993) Cecal fermentations in rats fed oligosaccharides (inulin) are modulated by dietary calcium level. American Journal of Physiology 264, G855-G862.

Scharrer E \& Lutz T (1990) Effects of short chain fatty acids and K on absorption of $\mathrm{Mg}$ and other cations by the colon and caecum. Zeitung Ernahrungswissenschaft 29, 162-168.

Scharrer E \& Lutz T (1992) Relationship between volatile fatty acids and magnesium absorption in mono- and poly-gastric species. Magnesium Research 5, 53-60.

Tahiri M, Tressol JC, Arnaud J, Bornet F, Bouteloup C, FeilletCoudray C, Ducros V, Pépin D, Brouns F, Roussel AM, Rayssiguier Y \& Coudray C (2001) Five week intake of shortchain fructo-oligosaccharides increases intestinal absorption and status of magnesium in post menopausal women. Journal of Bone and Mineral Research (In the Press).

Topping DL, Illman RJ \& Trimble RP (1985) Volatile fatty acid concentrations in rats fed diets containing gum arabic and cellulose separately and as a mixture. Nutrition Reports International 32, 809-814.

Trinidad TP, Wolever TM \& Thompson LU (1996) Effect of acetate and propionate on calcium absorption from the rectum and distal colon of humans. American Journal of Clinical Nutrition 63, 574-578.

Trinidad TP, Wolever TMS \& Thompson LU (1999) Effects of calcium concentration, acetate, and propionate on calcium absorption in the human distal colon. Nutrition 15, 529-533.

Van den Heuvel EGHM, Schaafsma G, Muys T \& Van Dokkum W (1998) Non-digestible oligosaccharides do not intefere with calcium and nonheme-iron absorption in young, healthy men. American Journal of Clinical Nutrition 67, 445-451.

Van den Heuvel EG, Muys T, van Dokkum W \& Schaafsma G (1999) Oligofructose stimulates calcium absorption in adolescents. American Journal of Clinical Nutrition 69, 544-548.

Yanahira S, Morita M, Aoe S, Suguri T, Takada Y, Miura S \& Nakajima I (1997) Effects of lactitol-oligosaccharides on calcium and magnesium absorption in rats. Journal of Nutritional Science of Vitaminology (Tokyo) 43, 123-132.

Younes H, Levrat MA, Demigné C \& Rémésy C (1993) Relationship between fermentations and calcium in the cecum of rats fed digestible or resistant starch. Annals of Nutritional Metabolism 37, 311-319.

Younes H, Levrat MA, Demigné C \& Rémésy C (1995) Resistant starch is more effective than cholestyramine as a lipids-lowering agent in the rat. Lipids 30, 847-853.

Younes H, Demigné C \& Rémésy C (1996) Acidic fermentation in the caecum increases absorption of calcium and magnesium in the large intestine of the rat. British Journal of Nutrition $\mathbf{7 5}$, $301-314$. 